Karin van Marle

Department of

Jurisprudence, University

of Pretoria

DOl: http://dx.doi.

org/10.18820/24150479/

aa49i1. 6

ISSN:0587-2405

e-ISSN: 2415-0479

Acta Academica - 2017 49(1): 103-115

(c) UVIUFS

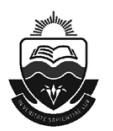

Review article

\section{The complicity of language, knowledge and justice}

Bloemfontein: SUN Press, 2016; 306 pages; ISBN: 9781920382780

\title{
Introduction
}

In reading Pieter Duvenage's Afrikaanse filosofie. Perspektiewe en dialoë (2016) other texts came to mind - Peter Vale, Lawrence Hamilton and Estelle Prinsloo's edited collection on Intellectual traditions in South Africa (2014); Andrew Nash's 2000 article on what he called 'the new politics of Afrikaans'; the majority and minority judgments in the case of City of Tshwane vs Afriforum; an article by Achille Mbembe on the decolonisation of the university, to name a few. In my reflection on Duvenage's perspectives and dialogues I recall my thoughts arising from these texts. I read his book also within the context of ongoing calls for radical transformation, decolonisation, and spatial and epistemic justice. 
Let me be candid about my own subjective lens that definitely influenced my reading of Duvenage's book. Afrikaans is my first language. I teach and do research in a faculty of law, in a department of jurisprudence. And I am a white female academic whose work is rooted in 'ethical' feminist theory. Given this, I am cautious about a project that specifies two things that I do not identify with immediately or instinctively and that recognises only ten white male philosophers as worthy to be included in this project. Not being sure what it involves, I do not see myself as 'Afrikaans' - as said above, I am a white first language speaker of Afrikaans. I am also not a philosopher. All my teaching and research fall within the area of jurisprudence, which can be defined, following Douzinas and Gearey (2005), as the consciousness/ knowledge and conscience/ ethics of law. At the same time being an Afrikaans speaker makes me complicit in the notion of 'Afrikaans', at least in the sense that I stop and wonder what 'Afrikaanse filosofie' means and might mean for me as an Afrikaans first language speaker. Philosophical texts and engagement with philosophical ideas have been central to my teaching, research, reflection and understanding of jurisprudence. Douzinas and Gearey (2005) lament the decline of jurisprudence when it was 'purified' from philosophy and other humanities disciplines. A general jurisprudence, one that I subscribe to, encompasses philosophy, literature and other humanities disciplines. Thus as far as philosophy appears in the title of Duvenage's book, it speaks to me and my work.

Duvenage's text is one of a number of works on intellectual history, or a history of ideas, that are important for contemporary discussions and debates on knowledge, research and the future of the university. Most pertinent is the hope that this kind of work might assist us in making sense of certain things in the present and future.

Over the past few years the issue of epistemic violence has become more prominent at South African universities and in the broader public discourse. Epistemic violence is raised often in the context of a call for decolonisation. In other words, emphasis is placed on the fact that colonialism was accompanied by coloniality and even when the former might end, the latter lingers, with the violence that comes with it. To simplify a more complex argument, one can say that by acknowledging epistemic violence we acknowledge the suppression, rejection and in some cases literal destruction (wiping out) of local, indigenous, and women's knowledge - all knowledge that did not emanate from the Western male centre. A process of decolonisation should also include a response to epistemic violence, a responsibility to allow for epistemic diversity and a striving for epistemic justice. What exactly decolonisation entails is, of course, heavily contested. 
In this review, I first bring together a piece by Achille Mbembe on what decolonisation might entail, and a court case on street names in the City of Tshwane. These two texts allow me reflect on the way in which spatial justice relates to epistemic justice and vice versa. I then bring together another philosopher and court case: Andrew Nash's reflections on what he calls "the new politics of Afrikaans" and the court case on the University of Pretoria's new language policy. Against this background, I present my reading of Duvenage's perspectives and dialogues.

\section{Decolonisation, street names and ideas from elsewhere}

Achille Mbembe $(2016: 29)$ reflects on decolonisation by recalling the contestation over the Rhodes statue by students on the UCT campus in early 2015. Mbembe supports the students who called for the statue to be removed and says there should be no place for statues, symbols, pictures or images that represent figures or people who negated the humanity of black people. On the issue of access to universities he argues that this entails much more than merely allowing students of all races to register to study at university. For him (2016:30), access to be meaningful should include "the possibility to inhabit a space to the extent that one can say, 'This is not a hospitality. It is not a charity.'" In this vein he argues that apartheid buildings/ infrastructure/ architecture "[are] not conducive to breathing".

The notion of inhabitance as opposed to hospitality or charity relates for me directly to the issue of the Western nature of the university, that universities are "local instantiations of a dominant academic model based on a Eurocentric epistemic canon" that so far have 'allowed' others to enter but only on the terms set by the traditional model (2016:33). The implication of a Western canon is that it values only Western notions of the truth and rejects all other forms of knowledge. For Mbembe an important feature of many Western epistemic traditions is their reliance on a certain division between 'mind and world', 'reason and nature', and on a detachment between the 'knower' and the 'known'. This point doesn't speak only to epistemology, ways of knowing, but also ontology, ways of being. Mbembe notes that the main problem of this form of epistemology and ontology is that they become hegemonic and do not acknowledge other ways of knowing and being.

At this point I want to relate to each other the notions of epistemic violence/ justice and spatial violence/ justice. As was clear from the \#Rhodesmustfall group it was never just the statue itself that was being challenged but also what the statue represented. At the same time it was also about the very materiality of 
that statue and the space it occupied. In challenging epistemology, students are challenging the space and place that is the university in all its facets.

In the matter of City of Tshwane Metropolitan Municipality $\vee$ Afriforum and Another [2016] ZACC 19 the Constitutional Court had to decide whether to uphold a restraining order that had been granted to Afriforum (a self-described 'civil rights' organisation advocating for the protection of the Afrikaans language) against the City of Tshwane that prohibited the city from removing old street name signs in Tshwane/Pretoria and replacing them with signs with new names. In the majority judgment delivered by Chief Justice Mogoeng, the court set aside the restraining order, allowing the city to proceed with changing street names. Mogoeng CJ starts his judgment by recalling South Africa's past, as reflected in the preamble of the Constitution. The gist of his narrative is how apartheid, as a system of institutionalised oppression based on an irrational differentiation between black and white that rendered black people as intellectually inferior and lesser beings, resulted in a situation where there was hardly any city, town, street or institution named after black people's historical leaders. Virtually all recognition and honour was given to white people and the history of white people. The chief justice remarked that "South Africa still looks very much like Europe away from Europe" (Mogoeng CJ City of Tshwane Metropolitan Council vs Afriforum Case CCT 157/15 par 120). Afriforum's main argument ironically rested on their sense of belonging being infringed by the removal of the old street name signs.

The case raised a number of technical issues that are not important here. Part of thinking about spatial and epistemic (in)justice involves a reflection on the notion of belonging: the Chief Justice - rightly to my mind - challenged Afriforum's reliance on belonging by invoking the sense of belonging of black South Africans living in Tshwane. The majority judgment speaks to how epistemic violence coincided with spatial injustice. Black people in Pretoria were not only forcibly removed, evicted from their houses and given space only on the outskirts of the city, but their history and memories and humanity were denied. I return below to the minority judgment delivered by Froneman I and Cameron I that raises a number of complexities in questioning the majority's claim that each and every invocation of white history inevitably will amount to racism.

Turning to Ngugi wa Thiong'o (1981), Mbembe (2016:34) talks about what could be involved in decolonising knowledge/ the university. He underscores relationality to ourselves and to others, which includes "in this age of the Anthropocene, all sorts of living species and objects" (2016:35). Ngugi supports the notion of decentering that entails a questioning of the idea that the West is the 'central root' of African consciousness and cultural heritage and rejects all attempts to set up Africa as a mere extension of the West. Mbembe regards the 
notion of decentering not as a rejection of all European traditions, but rather as a redefinition of what the centre is. Chakrabarty (2000) has similarly called for the 'provincialisation' of Europe. Mbembe summarises Ngugi's project as a call for "a geographical imagination that extends well beyond the confines of the nationstate" (2016:36; See also Cornell and Seely 2016) .

Decolonising the university, according to Mbembe, has two aspects. The first is the critique of the Eurocentric model that not only privileges European knowledge but excludes all alternative knowledges. The second is to start to imagine the other model. Theorists such as Walter Mignolo (2011), Boaventura De Sousa Santos (2007) and Enrique Dussel (2013) argue that knowledge can only be thought of as "universal if it is pluriversal". This notion of 'pluriversity' involves "a process of knowledge production that is open to epistemic diversity". It involves a "horizontal strategy of openness to dialogue among different epistemic traditions" (2016:37).

Peter Vale (2014: 1), in the introduction to the volume on intellectual traditions in South Africa, quotes Bertolt Brecht saying "[p] eople who understand everything get no stories". These words set the tone for Vale, who argues consistently against past and present attempts that insist on a grand narrative, closing the possibility of multiple stories and voices. He does not shy away from the fact that intellectual traditions were transplanted in South Africa from elsewhere, that epistemologies were brought here on ships by "bedraggled crews". The project of intellectual history is to unearth suppressed knowledges and to reconsider the ideas and traditions that shaped and are shaping South Africa. He insists "that this country was made by ideas, most (if not all) of which came here in languages that were intimately bound to the ideas they carried" (Vale 2014:5). Vale, and Hamilton in the conclusion, emphasise the mixing of ideas that took place in South Africa. They both argue for the importance of the future development of this intellectual history. Hamilton (2014: 341) calls for the "unearthing [of] older, often silenced opinions and ideas that [can] help us escape the constraints imposed on our imagination by history". There are several differences between this volume's approach and Duvenage's: the former is much more candid about past injustice brought about by epistemic violence, by the suppression of 'other' knowledges; they are also wary of adopting one narrative that can again suppress or exclude others; they are well aware of the importance of an interdisciplinary approach for intellectual history; there is no attempt to assert any form of identity on certain strands of thought.

Where does Duvenage's book stand vis-à-vis the calls for epistemic diversity and, in particular, epistemic justice? Is the attempt to demarcate a specific 'Afrikaanse filosofie' an opening or closure of pluralities? What is the point 
at this time, in this place, of demarcating and identifying a certain strand in philosophy as 'Afrikaans', given the calls for a decentering of Western knowledge? Johan Rossouw (2016:3), in his review of Duvenage's book, argues for the project of 'Afrikaans philosophy' to be read as a project of 'intellectual decolonisation'. For Rossouw the establishment of Afrikaans as academic language in general and philosophical language in particular counters the legacy of British colonialism in South Africa. He argues that intellectual decolonisation in South Africa should have a focus on the local context and that ideas even if they come from elsewhere could be of value for this project. He contends that the test for intellectual decolonisation is not the place of origin of the idea but how it is applied.

The chief justice in the Tshwane street name case raised the issue of belonging, and in so doing related issues of spatial injustice with epistemic injustice in a way that speaks also to the issue of the university and on a broader level the issue of intellectual history. I do not disagree with Rossouw's view that emphasis should be placed on the local context. However, I am concerned that as with Duvenage the move to set Afrikaans up as a decolonial language - even though it can be explained as such from a certain historical vantage point - comes too quickly, and comes before responsibility has been taken for past and enduring injustice. I turn below to Andrew Nash's writing in 2000 on the politics inherent in this understanding of Afrikaans.

\section{The politics of language}

Andrew Nash (2000) meticulously traces the way in which the ANC, most notably Thabo Mbeki, dealt with Afrikaners and Afrikaans in the mid 1990s and onwards. Nash explains how, by incorporating Afrikaners in the negotiations, Mbeki successfully neutralised the Afrikaner establishment and marginalised those Afrikaners who had always voiced their dissent to apartheid. Part of Mbeki's plan was to replace Afrikaans with English. Nash (2000:360) argues that the "elevation of English to de facto language of power, do[es] not benefit the majority of South Africans". For him it does not necessarily challenge the legacy of apartheid, and in some instances even continues it. However, it makes it easier for members of the black elite to enter the workplace and the economy, also public life, the media, education and elsewhere.

Nash discusses the views of people such as Breyten Breytenbach, Johan Degenaar and Andre du Toit as examples of dissenting voices against apartheid under apartheid. Du Toit is one of the philosophers interviewed by Duvenage. Nash (2000:344) recalls Breytenbach, who in 1976 said, "For Afrikaners to live on, Afrikaners must be prepared to "become compost, decomposing in order to compose other forms'." Nash also remembers Degenaar, also appearing in 
Duvenage's book, who, within the context of Elsa Joubert's Die swerffare van Poppie Nongena, said that Afrikaners should show solidarity with people who have been wronged, "whoever they may be" (2000: 345). A similar point was made by Du Toit (2000:347), with the added dimension that Afrikaner survival was inextricably linked to them having the "political and moral courage to act in solidarity with oppressed people". For Nash it is exactly on this aspect that the new politics of Afrikaans and its supporters fail. He argues that for all their reliance on republican politics, their defence of Afrikaans is one that falls squarely in the conception provided by liberal constitutionalism and the capitalist market (2000:348).

Nash's main claim (2000: 352) against the new politics for Afrikaans is that it never developed into a "larger programme of social reform" or engaged in any sustained way with "actual historical struggles". He argues that even though they offer a critique of capitalism and globalisation, their concern is not with the majority of people who suffer under the continued systemic inequality, but rather with a "cultivated minority, defined by their cultural values, philosophical premises and aesthetic sensibilities" (2000:353). My sense is that Duvenage's project can be seen as an example of Nash's analysis. The issue of the future of 'Afrikaanse filosofie' is made too prominent. I don't see a radical interrogation of the way in which certain philosophical perspectives were connected to or used to justify apartheid, nor an active attempt to respond to injustice, epistemic or spatial.

Nash's article was published in 2000 and over the past 16 to 17 years there have been some shifts. However, the recent brutal fights for Afrikaans in strong racial terms confirm much of Nash's view. Nash (2000: 361) predicted that the new politics for Afrikaans would turn into a protection for Afrikaans supported by "people who have a strong material interest in defending the fruits of oppression and exploitation, even if they no longer defend apartheid itself, and opposing any struggle for liberation which goes beyond formal equality to ensure that all South Africans can participate equally in the making of their future". Nash (2000: 362) also warned that this process would "forfeit the most valuable parts of the legacy of Afrikaner dissent in South Africa, and leave all South Africans the poorer". The recent court cases around the introduction of new language policies at public South African universities and the fierce battle for Afrikaans that surrounds these cases confirm this warning.

The issue of language has been prominent in the history of South Africa for many years. 16 June 1976 is remembered as the day when all over the country black youth rose against being forced to learn Afrikaans at government schools. Over the past few years the discussion about language of instruction at public 
universities has focused on the challenge to the continuous use of Afrikaans as language of tuition in formerly exclusively white Afrikaans universities.

The University of Pretoria (UP) adopted a new language policy in the middle of 2016, which replaced parallel tuition in English and Afrikaans with Englishonly tuition. It immediately faced a court challenge by Afriforum. Cases were also brought by Afriforum challenging language policies adopted by Unisa and the universities of Stellenbosch and the Free State. Kollapen J in his judgment in the UP case refers to language as being "considerably more than simply a means of communication; it has been recognised as central to human development and an inextricable part of the construction of human identity" (Kollapen, J Afriforum vs Chairperson of the Council of the University of Pretoria Case No: $54451 / 2016$ par 1). He argues that while language has played a positive role in affirming identity throughout history, there were many occasions where those in power used language to dominate, subjugate and exclude (Kollapen, J Afriforum vs Chairperson of the Council of the University of Pretoria Case No: $54451 / 2016$ par 2). The court had to decide on three issues: whether the newly adopted language policy infringed section 29(2) of the Constitution (the right to mother tongue instruction where 'reasonably practicable'); whether it infringed Section 9 (the equality clause) by discriminating unfairly on the basis of language; and whether the newly adopted policy constituted a breach of existing rights. The court ruled against Afriforum and in favour of UP on all three challenges, underscoring the role that the university can play in "advancing social cohesion and in providing an important intellectual space where South Africans, in their bewildering diversity, can together reflect on the kind of issues and debates that a young and vibrant society such as ours must confront" (Kollapen, J Afriforum vs Chairperson of the Council of the University of Pretoria Case No: 54451/2016 par 73).

The court ruling links to the notion of inhabitance invoked by Mbembe above. It shows how the issues of access, material equality, spatial equality are linked with the issues of epistemic violence and justice. Here one could ask again about the project of demarcating something as 'Afrikaans philosophy'; what are the underlying politics of this project, who is the community protected here, who is excluded from this community, and what are the implications for epistemic justice and epistemic diversity?

\section{Afrikaanse filosofie. Perspektiewe en dialoë}

Duvenage's book consists of a short introduction; a chapter in which he introduces what he calls the phenomenon of Afrikaans philosophy; two chapters in which he discusses firstly the pragmatist philosophy of Tobie Muller and secondly CK 
Oberholzer's role in establishing phenomenology at UP; and then dialogues with Piet Dreyer, Bert Meyer, Johan Degenaar, André du Toit, Danie Strauss, Bert Olivier, Johan Snyman and Danie Goosen. My aim in this review is not to engage with any of the chapters or dialogues in detail, but rather to reflect on the project of demarcating something as 'Afrikaans philosophy' in light of current debates and discussions on knowledge, language and justice. I start by looking more closely at the introduction and the chapter on the notion of 'Afrikaans philosophy'.

Duvenage (2015:ii) highlights continental, Reformation-oriented, and analytical as the three main traditions in 'Afrikaans philosophy'. He also mentions African philosophy that has come to the fore over the past two decades. He notes a number of issues that have been raised, namely the modern world and modernity; religion and science; the particular and the universal; thought and language; historical trauma and critique.

Duvenage (2015:ii) is candid about the autobiographical/ biographical angle in his work, saying that he was influenced by each of the people with whom he entered into dialogue; his interviews focus initially on a number of biographical aspects, studies, etc. I was reminded by Hamilton's (2014:342) observation that in writing intellectual history we need closer analysis of "ideas, especially via the exegesis and interpretations of texts and arguments" and less biography. Duvenage (iii) raises the issues of postcoloniality and gender and says that his investigation into 'Afrikaans philosophy' should not be seen as separate from the broader South African and African context. In terms of gender he says that there were not many women philosophers around in the period that he investigated. I respond to these aspects of context and gender below. He describes the aim of his work as attempting to find the starting point(s) of 'Afrikaans philosophy', to think about it as a phenomenon. In this description he drops the phrase 'Afrikaanse filosofie' and instead uses 'filosofie in Afrikaans', which seems to mean the same thing to him. Vale (2014:9), in the introduction of Intellectual traditions in South Africa, reflects on the decision to call the 13 traditions discussed in the book 'intellectual traditions in South Africa' rather than 'South African intellectual traditions'. I am interested in Duvenage's choice not to call his book, and ultimately his project, 'philosophy in Afrikaans' but 'Afrikaans philosophy'. What is at stake in the demarcation or identification of certain texts, certain work as 'Afrikaans philosophy'? A question that is central to his project, the only one that he highlights in the introduction and which he ends the book with, when it is posed to Danie Goosen, former chairperson of the FAK (Federasie van Afrikaanse Kultuur), is whether the phenomenon of Afrikaans philosophy has now come to an end: 'Dink jy ons het aan die einde van die verskynsel van Afrikaanse filosofie gekom? ... Trek ons nou 'n gordyn toe op " $n$ wêreld wat ons gevorm het en stap daarvan weg? Wat is die toekoms van kleiner tale en minderheidsgemeenskappe 
en gesentraliseerde magstate [Do you think that we've come to the end of the phenomenon of Afrikaans philosophy? ... Are we now drawing the curtain closed on a world that we formed and are we walking away from it? What is the future of smaller languages and minority communities and centralised sovereignties?] (Duvenage 2016: iii; 247-248)?

In Chapter 1, which deals with the phenomenon of 'Afrikaans philosophy', he starts by saying that 'Afrikaans philosophy' is a consequence of historical, social and cultural circumstances of more than 300 years, including the influence of British idealism, European continental thought (including phenomenology, existentialism, hermeneutics, critical theory and poststructuralism), logical positivism and analytical philosophy, religious lines of thought (such as Reformation philosophy and neo-Thomism) and African philosophy. Like Vale, he asks to what extent can one say that something such as South African and more pertinently Afrikaans philosophy exists, and if so what it might involve? The very next question is whether 'Afrikaans philosophy' would continue to exist or whether it would disappear. To my mind this question comes too quickly, before one has had time to consider the previous one; it assumes the existence of 'Afrikaans philosophy' and by doing so exposes what I regard as an urgency and flaw in Duvenage's project, namely what can be done to save this thing that he calls 'Afrikaanse filosofie'.

He makes the following preliminary remarks about the perspectives and dialogues in the book: 1) that one approaches the world from a specific framework; 2) that the emphasis of the book falls on the meeting and tension between certain patterns of thinking and thinkers and the South African historical reality; 3) that an Afrikaans philosophical tradition does not have the soil of cities and cultures such as Oxford, Paris or Heidelberg so one should rather refer to an Afrikaans philosophical approach than a tradition; and 4) that the book aims to give a historical and systematic insight into the phenomenon of Afrikaans philosophy. Thus he says that the aim is to look at the institutionalisation of philosophy in South Africa so as to understand from where it comes and how it changed under (post)colonial conditions. He then briefly considers colonialism and the institutionalisation of philosophy in South Africa. I would have liked to see a closer engagement with this aspect. With respect to André du Toit's work he raises several questions: What happens with thought under colonial and postcolonial conditions when social and material circumstances change? What is the relationship between state power and knowledge? What is the relation between the thinking subject and the power relations in which he or she stands? What does the philosophy curriculum look like (2016: 4)? Instead of pursuing these questions he returns to institutional history. He refers to Murray's picture of 'Afrikaans philosophy' and highlights four historical instances that gave rise to "a bigger philosophical conscience and 
identity in Afrikaans thought": 1) the intimate relationship between church order and the state; 2) a number of theological debates; 3) educational debates and 4) political and constitutional thought.

He ends the chapter by making some tentative remarks about 'Afrikaans philosophy', saying it could be seen as a response to British idealism and is influenced strongly by phenomenological thought associated with Husserl and later Heideg'ger's ontology, existentialism, hermeneutics, critical theory and poststructuralism. He connects the broad continental thought tradition with an openness towards religious, historical, ethical and aesthetical issues and argues that issues such as modernity and religion and science be seen as part of 'Afrikaans philosophy.' Duvenage looks at the relation between 'Afrikaans philosophy' and apartheid and refers to the 'uncomfortable fact' that the majority of philosophers supported apartheid, but leaves this in the air. He refers also to the exceptions, such as Martin Versfeld, Johan Degenaar and Daantjie Oosthuizen, who notably distanced themselves from apartheid.

For Duvenage the future of 'Afrikaans philosophy' remains open and his concern is about its continuance or disappearance. He poses several questions about the task of the 'Afrikaans philosopher' in current times: retreat or engagement with the new political and social circumstances? participation in the public sphere or not? Duvenage believes these questions can be answered only through a solid knowledge of the intellectual history of 'Afrikaans philosophy'.

I said above that I would return to the issue of how the author responds to postcoloniality and, more pertinently, decoloniality and also how he treats gender. I have throughout this review raised my concerns about the notion of 'Afrikaans philosophy', in particular given the current context where it is acknowledged that the pervasiveness of Western thought and knowledge should be challenged and decentered. I don't see in Duvenage's engagement with what he calls 'Afrikaanse filosifie' an attempt to take responsibility for past injustice. There is rather an attempt to protect the status quo and a fear of a decline.

Ultimately the perspective and dialogues taken up in the book involve 11 white Afrikaans-speaking men. Can the exclusion of women be justified by his statement that there were no women involved in institutionalised philosophy in the era that he focuses on? And even if it were true shouldn't the presence of 11 white male voices prompt one to expand the vision, to draw different lines? Other commentators (see, for example, Rossouw 2016) have also queried the exclusion of a number of thinkers: Martin Versfeld and Fanie de Beer, white males but not part of Duvenhage's group; Adam Small, a black philosopher and poet; Breyten Breytenbach, white male poet; Antjie Krog, white female poet and writer. I would add here, for example, women in university language departments - the 
exclusion of Marlene van Niekerk immediately comes to mind - who have made significant contributions to philosophical thought. The project could have been more inclusive had the focus on philosophy, and who is deemed to be writing and contributing to it, been broader.

I have been critical throughout this review on the identification of something as 'Afrikaans philosophy'. Thinking takes place within certain languages; I have referred above to Vale's link between the ideas and the languages that brought them here. The piece by Nash and also the language cases show the politics and power that come with language. I do not blindly support English, a sentiment I share with Nash. It is well known that Ngugi, writing on decoloniality, argued for African academics to write in African languages. As discussed above Rossouw in his review of Duvenage's book argues that Afrikaans philosophy should be seen as 'intellectual decolonialism' (2016:3). I am not only unconvinced by that argument but deeply concerned about how this might play out as a protection of 'existing rights'.

There is much potential value in researching and writing about intellectual history, as it could help us to make sense of the many complex issues that we must tackle in rethinking the university, research, curriculum and intellectual endeavours. I enjoyed reading the dialogues in the book, some more than others; depending on one's philosophical interest the different dialogues can offer not only information on the history of ideas and how they became institutionalised but also on specific concepts, notion and philosophers.

I said above that I would return to the Tshwane street name case. Froneman J and Cameron J open their minority judgment as follows: "The wounds of colonialism, racism and apartheid run deep. ... insensitivity to the continuing wounds by many of us who were not subject to these indignities can only exacerbate the fraughtness. So it is with humility that we dissent ..." [79]. Their dissent is based on two reasons; the first is of a technical nature on the rules and principles that apply to the grant of temporary interdicts that I will not pursue here. The second reason speaks to "the implication that may be drawn from the first judgment ... that any reliance by white South Africans, particularly white Afrikaner people, on a cultural tradition founded in history, finds no recognition in the Constitution, because that history is inevitably rooted in oppression". This aspect for them "invites deeper analysis" than that given to us by the Chief Justice. Many will criticise Froneman's and Cameron's judgment as being conservative and reactionary, and thus will fail to do the deeper analysis that they call for. Their judgment does not deny the fact of historical injustices, nor the continuance of historical advantage; they state without hesitation that they "disagree profoundly with Afriforum's view of history". They then say that "we think it would be better for white Afrikaans 
people, and indeed everyone else, to find their sense of place and belonging, not only in the past, but also in a shared future ..." (par 123). Intellectual history, even one of ideas coming from elsewhere, can play a valuable role in the search for a shared future, but only if it acknowledges past and enduring violence without reservation and works towards accountability, responsibility, de-centering and a continuous re-configuring.

\section{Bibliography}

Chakrabarty D (2000) Provincializing Europe: Postcolonial thought and historical difference. Princeton: Princeton University Press.

CoRnelL D ANd SeEly S (2016) The spirit of revolution. Beyond the ends of man. Cambridge: Polity Press.

De Sousa Santos B (ed) (2007) Cognitive justice in a global world: Prudent knowledges for a decent life. New York: Lexington Books.

Dussel E (2013) Agenda for a South-South Philosophical Dialogue. Human Architecture: Journal of the Sociology of Self-knowledgeXI (1):3-18. https:// doi.org/10.13185/BU2013.17101

DOUZINAS D AND GEAREY A (2005) Critical Jurisprudence. The political philosophy of justice. Oxford: Hart.

Duvenage, P (2015) Afrikaanse filosofie. Perspektiewe en dialoë. Bloemfontein: SUN Press.

Mbembe, A 'Decolonizing the university: NeW directions' (2016) Vol 15 (1) Arts \& Higher Education 29-45.

Mignolo W (2011) The darker side of western modernity. Durham: Duke University Press. https://doi.org/10.1215/9780822394501

Nash, AndreW. 2000. "The neW politics of AfrikaAns." South African Journal of Philosophy 19 (4) 340-364. https://doi.org/10.1080/02580136.2000.11 644283

Rossouw, J (2016) Afrikanerdenkers in die skadu van apartheid: Oor Pieter Duvenage se Afrikaanse filosofie: Perspektiewe en dialoë. LitNet http:// www.litnet.co.za/litnet-akademies-resensie-essay-afrikaanse-filosofieperspektiewe-en-dialoe-deur-pieter-duvenage/ accessed 7/25/2017.

Vale P, hamilton L and Prinsloo eh (2014) Intellectual traditions in South Africa. Ideas, individuals and institutions. Pietermaritzburg: UKZN Press.

\section{Cases}

Afriforum vs Chairperson of the Council of the University of Pretoria CASE NO: 54451/2016.

City of Tshwane Metropolitan Municipality v Afriforum CCT 157/15. 